\title{
Blue uncertainty: Warding off systemic risks in the Anthropocene-Lessons from COVID-19
}

Pablo F. Méndez

Institute of Innovation and Knowledge Management, INGENIO (CSIC-UPV), Universitat Politècnica de València, Edificio 8E, Camino de Vera, s/n, 46022 Valencia, Spain

Corresponding email address: pfmendez@upv.es

Peer-reviewed version of a manuscript accepted for publication on February 19, 2021.

\begin{abstract}
COVID-19 has made evident the complex interdependence of social and ecological systems and that to reduce the risk of future zoonotic pandemics we must safeguard nature. Approaches based on complexity science taking into account that interdependence and its associated systemic risks must be mainstreamed in current policy making, in general. However, at present, that could result in failure for three main reasons: (1) those approaches might be too sophisticated for current policy making pursuing sustainable development; (2) the reductionist views from conventional economics still deeply influence economic and environmental policy making; (3) it is unlikely that far-reaching policies aimed at stimulating post-pandemic economic development can be steered through radically innovative approaches that remain untested. Here, using COVID-19 as an example, I suggest that the use of innovative complexity-based approaches could be enabled through intermediary approaches equipped to resonate with the mindset pervading current policy making.
\end{abstract}

Keywords: COVID-19; Anthropocene risk; radical uncertainty; adaptive inference; modulating contingency; blue uncertainty 


\section{Introduction}

The Coronavirus Disease 2019 (COVID-19) pandemic, caused by SARS-CoV-2, is pushing political, healthcare and socioeconomic systems, and people, to their limits worldwide. Its first waves have impacted with a swiftness that have caught countries and local communities off guard, exposing our ill-preparedness to respond to a global health emergency of catastrophic magnitude. Thankfully, warnings from international and local authorities and experts, have progressively influenced the implementation of containment policies across the world as the pandemic has hit locally since March 2020 — although with notable differences in their timing (early vs delayed), approach (herd immunity vs suppressed equilibrium) and depth (mitigation vs suppression) (Huang et al. 2020, ILO 2020, Ritchie et al. 2020). During containment and subsequent de-escalation stages, those differences have certainly resulted in different applications of similar policy measures (e.g., social distancing, testing and tracing, confinement, self-care and personal hygiene) as countries have learned by doing, followed expert advice, or reacted to new information or socio-political pressures (Desvars-Larrive et al. 2020, ILO 2020). In general, it is fair to say that, at least until now, the main aim worldwide has been to protect the vulnerable populations and to not overwhelm public healthcare systems, and thus save as many lives as possible.

As I write from Spain, countries around the world are in different stages of the pandemic. While some countries and regions currently face new contagion waves, others are slowly leaving behind the first ones and de-escalating from pandemic-enforced measures. Nobody can really know when we will be able to proceed as safely as possible to a future already called the "new normal". In the interim, we already have sufficient information to thoroughly examine what has just happened, learn the lessons and enhance prevention, early warning and preparedness mechanisms to deal with future outbreaks internationally - so that they do not reach global pandemic levels. Indeed, whether or not we are heading to a long-term succession of infection peaks or waves, policy makers, experts, organizations and the civil society around the world are now reflecting about the best courses action for designing prevention and containment measures that do not jeopardize socioeconomic recovery in the post-pandemic future (DesvarsLarrive et al. 2020, ILO 2020).

But as critical as that exercise is, we should also be able to seize this as a unique opportunity to be more ambitious than ever and go beyond the surface. COVID-19 has made more evident than ever the inextricable and complex interdependence and mutual vulnerability of social and ecological systems, and that to reduce the risks associated to future zoonotic pandemics we must safeguard nature (Gordon 2020, Naidoo and Fisher 2020, Settele et al. 2020). Its acute impact must not blind us to the fact that this crisis might be just symptomatic of higher threats and systemic risks due to climate and global environmental change, which are just round the corner, and there won't be a wave period between them and COVID-19 (UNEP 2020). While we try to understand the phenomenon, other episodic shocks (e.g., financial crashes, disease outbreaks, large-scale environmental migrations) have been looming over us for decades, increasing their speed of propagation at a planetary scale and posing high systemic risks (Keys et al. 2019, Andersen and Rockström 2020). The level, scale and depth of our response to 
confront the current pandemic could be a portent of our readiness to tackle those systemic risks and global threats in the near future (Phillips et al. 2020). Although the current global strategy continues to respond only through public health measures and technological solutions-most notably the design and distribution of therapeutics and vaccines (IPBES 2020) - , we seem to be in the right path. There is evidence from the media (e.g., The New York Times 2020) and supranational policy (e.g., GNDE 2020) narratives suggesting rising awareness about the double role of nature as a protective space for human survival and as critical for socioeconomic recovery (IPBES 2020, World Economic Forum 2020). Approaches like Anthropocene risk (Keys et al. 2019) and One Health (see e.g., Waltner-Toews 2017, Scagliarini and Alberti 2020), were designed to address global systemic risks and the complex, adaptive and uncertain dynamics of connected systems of people and nature.

However, at present, the mainstreaming of those approaches in current policy making could result in failure for three main reasons, in general. Firstly, those approaches might be too sophisticated for current policy making pursuing sustainable development, which is largely siloed (OECD 2019), and based on the prescription of blueprint, panacea solutions to highly complex social-ecological problems (Ostrom 2007). Secondly, the reductionist views from conventional economics still deeply influence economic and environmental policy making (Foxon 2013, Thornton 2018, Maechler and Graz 2020), hindering the entry of complexitybased approaches into the mainstream. Thirdly, it is unlikely that far-reaching policies aimed at stimulating post-pandemic economic development can be steered through radically innovative approaches that remain untested-and even less when decisions seem to have already been made and there don't seem to be international concerted action on systemic risk assessment.

Here, using COVID-19 as an example, I suggest that the use of innovative complexity-based approaches in policy making aimed at managing global environmental systemic risks could be enabled through intermediary approaches equipped to resonate with the mindset pervading current policy making. Focusing on the containment and prevention stages, I first propose to understand the response to unexpected systemic threats as instances of reactive policy making driven by radical uncertainty. Then, I propose three notions that could enhance that understanding, as well as the scientific policy support required in conditions of high systemic risk and uncertainty, namely modulating contingency, adaptive inference and blue uncertainty. My hope is that this approach can contribute to a more robust foundation for policy and decision making in the face of Anthropocene risk.

\section{Radical uncertainty and lessons from the containment of COVID-19}

With COVID-19 experts and decision makers were facing, as it unfolded in real time, an unanticipated problem that was showing extremely "wicked" (Rittel and Webber 1973) and certainly falls within the realms of "Post-Normal Science" (Funtowicz and Ravetz 1993) - see Table 1 for a description of criteria. The question that will hold relevance for some significant time is whether the pandemic was entirely unpredictable. The discussion has already started (see e.g., Frankel 2020, Frutos et al. 2020, IIF 2020, McGillivray 2020) and it is subjected to 
ambiguity, at both epistemic level-uncertainty about the facts and nature of the phenomenon-and strategic level-low consensus about the facts and nature of the phenomenon due to political differences (Hall 2017).

Table 1. COVID-19, a post-normal wicked swan.

\begin{tabular}{|c|c|}
\hline Criterion & Description \\
\hline $\begin{array}{l}\text { Wickedness } \\
\text { (Rittel and } \\
\text { Weber 1973) }\end{array}$ & $\begin{array}{l}\text { - Real-time solutions couldn't be judged right or wrong, but just better or worse, since } \\
\text { they could only be tested trial-and-error; otherwise, it would have involved deciding } \\
\text { on who lived and who died. } \\
\text { - Responsibility for those decisions was anyway passively transferred from the political } \\
\text { level to healthcare workers. } \\
\text { - The pandemic is a symptom of more profound global problems, but they cannot be } \\
\text { tackled now, since resources are scarce and directed towards the resolution of the } \\
\text { symptom, as are political action, and media and public attention. }\end{array}$ \\
\hline $\begin{array}{l}\text { Post-normalness } \\
\text { (Funtowicz and } \\
\text { Ravetz 1993) }\end{array}$ & $\begin{array}{l}\text { - Decisions were made about a highly complex challenge. } \\
\text { - The facts were highly uncertain. } \\
\text { - Many values were in dispute. } \\
\text { - } \quad \text { The stakes were high and the decisions urgent. }\end{array}$ \\
\hline $\begin{array}{l}\text { Black-swanness } \\
\text { (Taleb 2007) }\end{array}$ & $\begin{array}{l}\text { - Being an outlier, because nothing in the past can convincingly point to its possibility, } \\
\text { hence it lies outside the realm of regular expectations: history shows that infectious } \\
\text { diseases, epidemics and pandemics occur regularly and, despite, as shown above, } \\
\text { COVID-19 was difficult to predict, it can take decades until we know whether it will } \\
\text { be an outlier on the plot. } \\
\text { - Carry an extreme impact: the pandemic is carrying an extreme impact, psychological, } \\
\text { socioeconomic, on our health systems and, in the near future, chances are that there is } \\
\text { a rebound effect on the environment. } \\
\text { In spite of its outlier status, an explanation is sought after the fact, hence making it } \\
\text { predictable in hindsight: while this criterion can be understood as normalizing an } \\
\text { event by rendering it predictable in hindsight (McGillivray 2020), I conceive it here as } \\
\text { the possibility for abductive reasoning, i.e., producing inferences to the best } \\
\text { explanation as the pandemic unfolds, based on past knowledge. }\end{array}$ \\
\hline
\end{tabular}

The epistemic level, moreover, has two sides of the argument pertaining to the issue of prediction and forecasting in science ${ }^{1}$, and, in principle, both sides do not seem incompatible: (a) the conjunction of events leading to the pandemic as rare enough to be characterized as an unpredictable accident ${ }^{2}$ for which we could not have been prepared (see e.g., Frutos et al. 2020); (b) that we already had certain capacity to forecast the occurrence of the pandemic based

\footnotetext{
${ }^{1}$ Here, a prediction is understood as an expectation (e.g., value of a random variable) in relation of an information set (e.g., combination of values of predictor variables), calculated through a model obtained, for example, by a fit to some available data (e.g., predictive curve). Prediction turns forecasting when the predictor is time (a continuous variable), and expected values can be derived outside of the range of observed time points through extrapolation.

${ }^{2}$ Frutos et al. (2020) define unpredictable accident as "the occurrence of a very low probability event resulting from the stochastic conjunction of independent low probability events", referring to the conjunction of events that they describe in their article in more detail.
} 
on rough extrapolations from past outbreaks or, more importantly, on existing knowledge about risk factors for human disease emergence (Morse 1996, Taylor et al. 2001, Cheng et al. 2007, Ge et al. 2013, Menachery et al. 2016).

What seems clear for now is that the compound effect of several factors made a reactive containment response to the pandemic unavoidable from the outset (Fig. 1). First, there was a logical unawareness of local communities and authorities from Wuhan (China) about SARSCoV-2 emerging in the wild and being zoonotically transmitted to humans in anthropic environments (Fig. 1). Transmission and infection then remained stealthy during a phase of latency (Fig. 1), which lasted until an outbreak of a "respiratory contagion owing an uncharted etiology" was first reported in Wuhan ${ }^{3}$ (Kumar et al. 2020). By way of an amplification phase, the epidemic was well underway in December-January 2019, driven by a tight combination of key social and virological/disease factors (Fig. 1) (Frutos et al. 2020, He et al. 2020). For Frutos et al. (2020), these events, in conjunction with globalization factors such as international hyperconnectivity and high-mobility of people (Fig. 1), constituted a rare "planetary alignment" that led to the emergence of the pandemic.

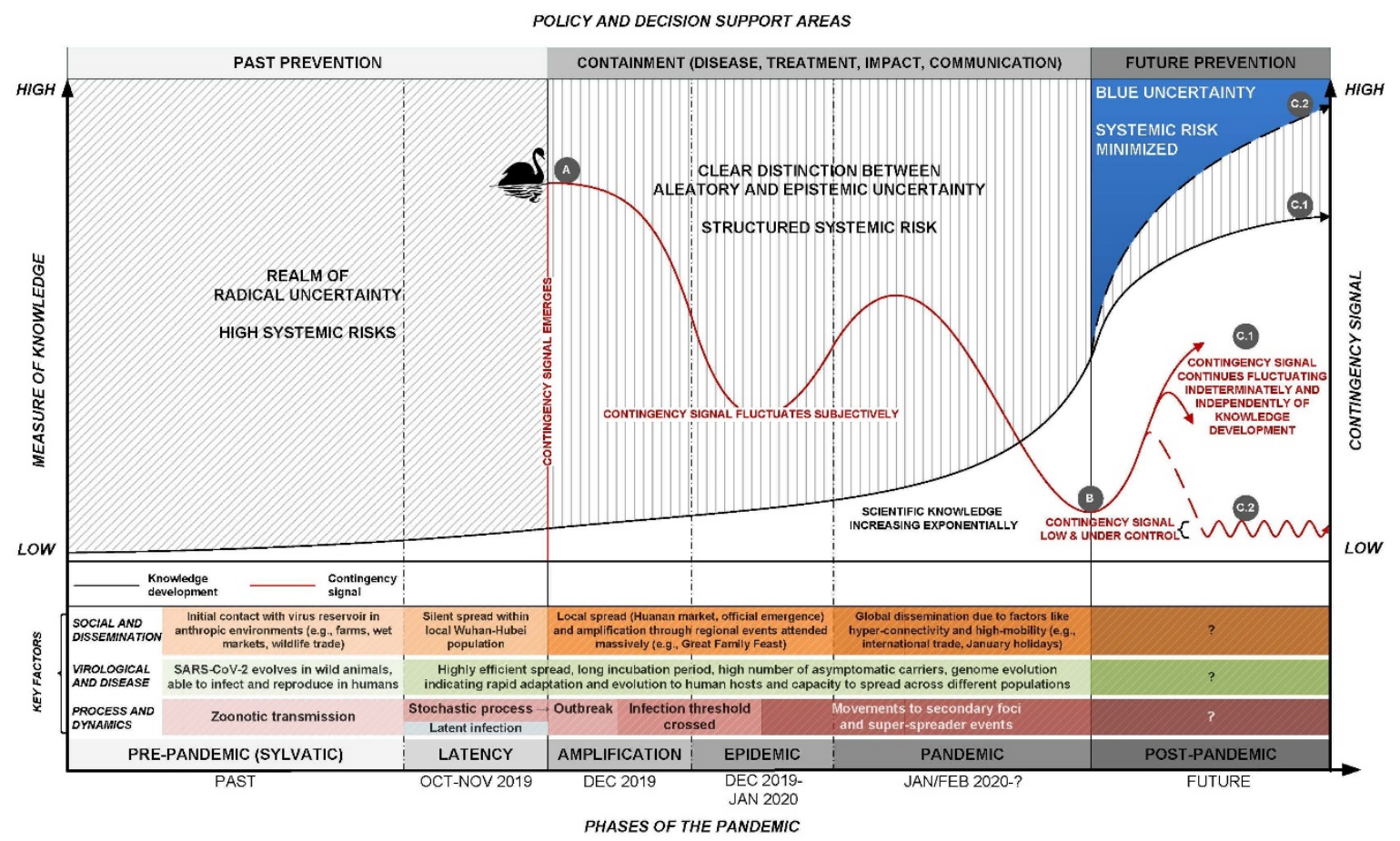

Figure 1. Stylized representation of a measure of our knowledge about pandemics (left y-axis, black arrow) and of the contingency signal (right y-axis, red arrow), against a description of key factors for the emergence of the pandemic through several phases (x axis, based on Frutos et al. 2020, Hen et al. 2020, van Dorp et al. 2020). Policy and decision thematic areas requiring support from science are represented at the top, as corresponding to the phases of the pandemic (based on the Global Health Interdisciplinary Platform of the Spanish National Research Council CSIC, created as a response to the pandemic, https://pti-saludglobalcovid19.corp.csic.es/). Black swan clipart: http://clipart-library.com (Not for commercial use).

\footnotetext{
${ }^{3}$ The contagion agent was termed as "novel corona virus 2019" by the World Health Organization (WHO) on 29th December 2019, and as SARS-CoV-2 on 11th February 2020 (Guo et al. 2020).
} 
This alignment of events moves in the quicksand of radical uncertainty (Kay and King 2020), which distinguishes between resolvable and radical uncertainty. ${ }^{4}$ In that view, resolvable uncertainty can be fixed through known probability distributions of outcomes, whereas radical uncertainty represents something that "we simply do not know" and cannot be described in probabilistic (game-like) terms - due to, for example, obscurity, ignorance, vagueness, ambiguity, ill-defined problems, or a lack of information (Kay and King 2020). During the prepandemic phase, we might have known that a new outbreak was possible based on rough forecasting. However, despite all the extant knowledge about emerging diseases and globalization, at the outset of the amplification phase of the pandemic (Fig. 1) we lacked the capacity to predict, with high precision and accuracy, the complex sequence of events that led to it-and much less to foretell its evolution and exact casualty numbers. Indeed, compartmental SIR-like models, one of the dominant modeling paradigms supporting policy during the pandemic, while informative about the likelihood of potential trajectories and future opposing scenarios in short-time prediction horizons, are unable to predict how the intermediate and late stages will develop - due to unavoidable uncertainties, instabilities and high sensitivity to small variations linked to model parameters and data scarcity (Castro et al. 2020). We were confronting radical uncertainty and high systemic risks (Fig. 1) and, to effectively respond to them, hard containment policies had to be designed and implemented, based on the best available evidence and epidemiologic models. And the arrow of time cannot be rerun to verify whether historical empirical reality would have reflected the outputs yielded by the imperfect models that informed containment policies (Eker 2020, Ioannidis et al. 2020, Panovska-Griffiths 2020,). ${ }^{5}$ Nor we will ever know whether current forecasting scenarios would live up to the test of future empirical evidence, because governments will surely adjust their policies, in one or another direction, depending on them. But let us consider the following counterfactual: what if governments had not followed expert advice, even when it was based on models readily available, and in spite of their flaws? What if they had postponed critical decisions until more suitable models were ready?

The key argument here is that thousands of lives could have been lost, if we have had to rely on more suitable models that still had to be calibrated to adjust to a new contagion agent. Some

\footnotetext{
${ }^{4}$ Kay and King (2020) have recovered an old debate between two extreme understandings of the risk-uncertainty dyad in economic analysis and economic policy, a debate presumably lost by the proponents of the perspective that Knight (1921) and Keynes (1921) pioneered a century ago. The perspective that won the debate, and is challenged again by the authors, marked profoundly the course of the economics discipline in the second half of the 20th century. For that perspective uncertainty can be fully described through the derivation of probability distributions for alternative outcomes of present actions and, more generally, that the world can be predictable in a scientific law-like way, through formal (and elegant) axiomatic reasoning and mathematical modelling. See also the views expressed by North (2005) that the terms had previously undergone some semantic alteration with uncertainty coming to refer what Knight meant by risk and the term ambiguity coming to refer to what Knight meant by uncertainty. In that view, the conceptual boundary between risk and uncertainty blurs. Uncertainty is considered as fully describable through probabilistic reasoning (as when used to formalize games of chance), and risk as a descriptor of uncertainty that can be minimized through a reiteration of probabilistic reasoning in order to discover alternative outcomes and their frequencies (as when games are repeatedly played). That approach claims that we know more about the future than we actually do, assumes that we can assign probability distributions to radical uncertainty and excludes the possibility for "unknown unknowns" (i.e., the realm of phenomena for which there are no precedents and are therefore hard to imagine).

${ }^{5}$ In the most relevant cases (Ferguson et al. 2020, Ioannidis et al. 2020) those models were wrong in orders of magnitude and supposedly flawed (see e.g., Ball 2020 for a scrutiny of Ferguson's et al. modeling approach).
} 
of those models, based on the probabilistic understanding of heavy-tailed phenomena (e.g., Extreme Value Theory), allow for enhanced inferences about the complex, clustering, and nonlinear nature of outbreak-epidemic-pandemic dynamics in a hyper-connected world (see e.g., Bar-Yam 2020, Cirillo and Taleb 2020, Moore 2020, Norman et al. 2020). Moreover, those models are explicit (and overtly honest) about key philosophical underpinnings (e.g., naïve empiricism; Norman et al. 2020), and factor in measures (e.g., standard contact tracing, doorto-door monitoring of symptomatic carriers) that, despite being culturally contentious in some countries, could have supported less-stringent containment measures (e.g., Shen et al. 2020).

However, current models, whether compartmental or complexity-based, are not yet able to represent the full complexity of biophysical and socio-technical realities, and of behavioral responses to that reality. There might be failures at technological (e.g., faulty technology for testing-and-tracing; Woloshin et al. 2020) and medical (e.g., diagnostic errors contributing to harm in health care; Gandhi and Singh 2020) levels. Moreover, there is still high uncertainty about how post-recovery immune protection and environmental and seasonal influences affect transmission dynamics (Kissler et al. 2020). And, on top of that, social reality is affected by ideology, politics and power dynamics, which, in turn, are characterized by cultural differences and reflexivity, so the questions arise: how can those models a priori account for strategic ambiguity at political level, for cultural differences in elderly care, for differences in citizens' compliance with public health measures in situations of social unrest, or for the promotion of untested (or even worse, deadly) remedies from authoritative sources? My view is that all these questions and epistemic tensions can turn more productive, informative and realistic if they are informed by the three epistemological notions that I describe next through an exercise of scientific foresight.

\section{Modulating contingency, adaptive inference and blue uncertainty}

To frame my argument, I will rely on the criteria that an event or outcome must fulfil to become a "black swan" (Taleb 2007), seizing the power of the concept to think in probabilistic terms in order to introduce what I understand by 'modulating contingency'-I am not seeking confirmation that COVID-19 constituted a "black swan" event. ${ }^{6}$ If we think in through blackswanness criteria (see Table 1), our assessments about the predictability of the pandemic after the fact become, consciously or unconsciously, structured within a specific epistemological tension between two extreme senses of contingency (Fig. 2). Between them, a continuum of predictability unfolds, with randomness equating a high level of unpredictability and contingency a property that can be modulated (Méndez et al. 2019).

\footnotetext{
${ }^{6}$ My view, as that of Taleb (see e.g., Avishai 2020), is that COVID-19 is not a "black swan". However, upon outbreak, the pandemic resembled the features of that concept, more as an uninformed perception of the contemporary observer, than as the informed opinion of the same observer later in time, able to better substantiate her judgments from the vantage point of retrospective analysis.
} 


\section{TWO SENSES OF CONTINGENCY}

(Mahoney 2000)

\begin{tabular}{|c|c|}
\hline $\begin{array}{l}\text { (1) "inability of theory to predict or explain, either } \\
\text { deterministically or probabilistically, the occurrence of a specific } \\
\text { outcome," hence a contingent event is "an occurrence that was } \\
\text { not expected to take place, given certain theoretical } \\
\text { understandings of how causal processes work" }\end{array}$ & $\begin{array}{l}\text { (2) some events or behaviors are part of a "non-systematic } \\
\text { variation inherent in the world that cannot even in principle be } \\
\text { eliminated from causal theories," hence inexplicable, contingen } \\
\text { events are an inextricable part of causal explanations about } \\
\text { real-life phenomena }\end{array}$ \\
\hline
\end{tabular}

MORE GENERALLY

Event/outcome at odds with analysis assessed as contingent because they are..

..either unforeseen by the set of general principles or propositions of the analytical framework, theory, or model at work. or random phenomena of an inherently stochastic world (e.g chance, freewill, agency, natural disasters)

Figure 2. Epistemological tension between two senses of contingency (based on Mahoney 2000, Eagle 2005, Méndez et al. 2019).

Applying those notions to COVID-19, an initial sense of randomness can be understood as a contingency signal emerging as the fact is known, at some point between November and December 2019, i.e., the situation resonates with the criteria defining a black swan (point A, Fig. 1). Then, the contingency signal fluctuates subjectively, depending on the epistemology at work (e.g., theories and models used by expert advisory groups), but is generally decreasing as new evidences are gathered, knowledge generated, and results and insights shared and discussed across the policy and scientific communities (signal decreasing toward point B, Fig. 1). Using terms from Kay and King (2020), we enter a stage of solving "mysteries" imbued with vagueness and indeterminacy, and the best we can do is asking "what is going on here" and start framing the problem "by identifying the critical factors and applying some sense of how these factors have interacted in the past and might interact in the present or future". Making use of abductive reasoning and retrospective methods (e.g., counterfactual experiments, retrospective analysis), a number of competing theories, models and explanations start to emerge about, for example: the evolution of SARS-CoV-2 through its sylvatic phase, its "zoonotic jump" and stochastic latency and amplification phases, the evolution of the epidemic into a pandemic, and the impact and prevention of the latter through the lens of multiple disciplines. We are in a stage during which we start structuring the systemic risks that we were facing, and progress toward a clear distinction between (1) the known unknowns (aleatory uncertainty, e.g., past knowledge describe regular outbreaks and potential predictors, but they are subject to probabilistic variability), and (2) the unknown unknowns (epistemic uncertainty, e.g., every virus evolution and outbreak dynamics are so different that the effect of potential predictors and contextual differences might vary enormously).

At some point, we enter the so-called "new normal" and knowledge development enter a new stage in which it starts to settle - as Kay and King (2020) would put it, we have many of the pieces of the "puzzle" and start putting them together. At that stage, though, epistemic uncertainty is still very high, because the unknown unknowns still abound. During the postpandemic, we will face, at least, two main scenarios regarding contingency and uncertainty. In the first scenario (C.1; Fig. 1), we have failed to assemble whole systems, transdisciplinary teams working to solve Anthropocene risk challenges, so there is still great epistemic uncertainty and the contingency signal remains dependent on subjective judgement. In a 
second, best case scenario (C.2; Fig. 1), we have successfully assembled whole systems transdisciplinary teams able to address Anthropocene risk from a holistic perspective, so we progress to minimize uncertainties and systemic risk to the utmost. We have kept contingency controlled at low levels, due to the collaboration of diverse stakeholders and multiple disciplines conceptualizing, observing, understanding or generating knowledge in general about the same problem, combining diverse perspectives and epistemological lenses. These teams and communities work and reason through frameworks similar to adaptive inference (Holling and Allen 2002), which can be used as a long-range protocol to develop and test competing perspectives, theories, models and hypotheses. These are tested step wise as information is collected through iterative empirical research, until they reach a maturation point, and our assumptions are challenged as we increase our learning and improve our conceptual thinking (Fig. 3). Since this scientific progress would be happening in the realms of basic blue-sky research with the main aim of reducing the systemic risks associated to the Anthropocene, I have coined the term 'blue uncertainty' (Fig. 1) to refer to a type of randomness inherent in the world that perhaps we will be never able to eliminate from our causal theories, predictions and models (based on Mahoney 2000).

Although the call for this kind of approaches is not new (Angelstam 2013, Brandt 2013), a greater diffusion and upscaling of complexity-based transdisciplinary approaches into the policy process has become more urgent than ever (Mallee 2020, OECD 2020). Taking a holistic approach that addresses the fundamental drivers of COVID-19 and current systemic risks, and involves those directly suffering the consequences of global environmental change, seems inescapable. It is true that such an approach poses fundamental challenges at both philosophical level (e.g., epistemological tensions between prediction-as in coin tossing-and understanding - as in puzzle solving) and governance level (e.g., who is to be involved, how decisions will be made, and power asymmetries or conflicts resolved). However, we can rely on the experience and know-how that existing complexity- and systems-based scholarship has accumulated during the last decades working hand in hand with practitioners, stakeholders, and the civil society, in a myriad of participatory initiatives on the ground ${ }^{7}$. For assembling these teams and their broader communities, and decide on just and equitable compositions and structures, a multiplicity of legitimate approaches can be followed. Recent advancements highlight the key role of knowledge co-production involving multiple groups of people with diverse needs and interests, to address the current planetary conditions that threaten social and ecological wellbeing (Norström et al. 2020, Vincent et al. 2020).

With a focus on the policy process and the co-production of knowledge, whole systems transdisciplinary teams and communities must have the following features (based on Cairney 2020, Molas-Gallart et al. 2020, Norström et al. 2020):

\footnotetext{
${ }^{7}$ Examples that swiftly come to mind are sustainability science, resilience, social ecology, Earth Systems Governance, and sustainability transitions scholarship. Single disciplines, including mainstream economics, have also been collaborating successfully with complex systems scholars for decades (e.g., Arrow et al. 1996, Sachs et al. 2019), although sometimes complexity economists strikingly continue to miss the opportunity to integrate nature more holistically into their analyses, frameworks and models (e.g., Arthur et al. 2019).
} 


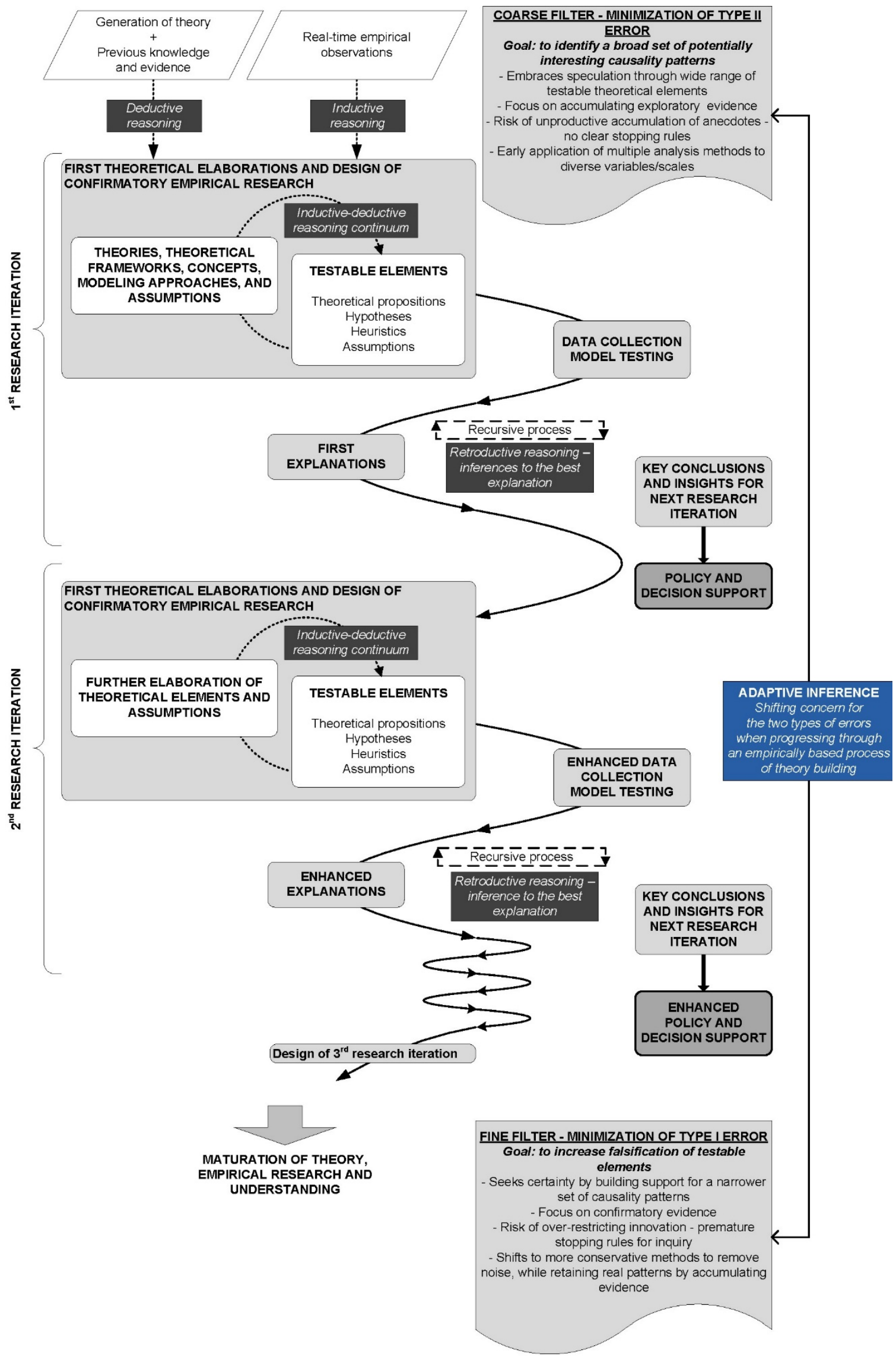

Figure 3. Adaptive inference protocol (based on Holling and Allen 2002, Méndez et al. 2019). 
1. Context-driven and place-based, to appropriately address the surrounding socialecological circumstances, governance levels and spatiotemporal scales.

2. Inclusive and pluralistic, acknowledging power dynamics and diverse ways of doing and knowing (e.g., feminist theory, traditional ecological knowledge).

3. Problem-focused and reflective, allowing for developing collective understandings of challenges through iterative mechanisms for incorporating learning from new information gathered, knowledge generated and feedback received, and embracing uncertainty and surprise.

4. Shifting the learning focus from hierarchic mode (based on the authority of powerful actors, irrespective of their knowledge), to other modes making uncertainty, knowledge and power relationships explicit on demand: bargaining mode (situations of low uncertainty and rich repertoires of solutions that are negotiated); reflection mode (high uncertainty and no single expert authoritative source, obliging actors to reflect on competing sources); or epistemic mode (high uncertainty reduced through strong interactions between policy makers, stakeholders and an authoritative body of knowledge) (see Cairney 2020:211).

5. Formative in their approaches to policy evaluation, conducting policy design, implementation and the very process of evaluation through processes of co-design and co-creation with the community of stakeholders, and making failure and the whole policy process an opportunity to learn from experience and to challenge different theories and perspectives.

From the science side, an improved understanding of the multiple dimensions of COVID-19 and, in general, global environmental change and the management of their associated systemic risks, requires a well-tuned balance of researchers from different disciplines of the social, natural and health sciences. For example, going beyond the usual suspects, the inclusion of behavioral scientists could help to understand whether or not different types of cognitive biases (e.g., probability neglect - related riskier individual behaviors-, or omission bias - related to the refusal to get vaccinated) are at play at individual, collective or political levels, and to what extent do they affect policy actions that can tip the scales in one direction or the other at critical, threshold moments (Halpern et al. 2020, Sieron 2020). Also, there are still scarce integrated studies about the effects of compliance with introduced prevention, contention or lock-down measures at different times of the pandemic, or about the influence of spatial, density and mobility factors (e.g., distance from outbreak epicenters, connectivity and clustering) - mainly due to a combination of a dearth of data and poor operationalization of variables from a comprehensive, interdisciplinary perspective (Bontempi et al. 2020).

Multi-sectoral collaborations focusing on health and social care, could result in improved education and training regarding hygiene routines and infection control measures, and an increase in the use of digital technology to monitor medication adherence and enhance psychosocial well-being, especially of older people and their families (Baxter et al. 2020). Indeed, the WHO has recently issued a framework document to support member states in the prevention of "pandemic fatigue", calling for going beyond the biomedical sciences towards strategies to maintain and reinvigorate public support, informed by public health, societal, 
cultural and economic considerations" and ensuring that "no one is left behind" (WHO 2020). In general, in this scheme, while the biomedical and health-related disciplines focus on more granular factors (e.g., genes, disease, treatments), the social or social-ecological disciplines focus on understanding the big picture (e.g., socio-economic effects of the pandemic, relationship between land-use change and zoonoses, regional resilience and vulnerability to external shocks).

\section{The normative side}

My approach is contingent on a global concerted "mental leap" (Lee 2012) toward a narrative focusing on robustness and resilience in complex systems à la Kay and King (2020) that then might morph into a more sophisticated one fully unpacking the Earth-system and socialecological aspects of complexity-based approaches such as One Health or Anthropocene risk à la Keys et al. (2019) — or any other approach focusing on the complex, intertwined and uncertain relationship between people and nature. Normatively, such a leap must thoroughly consider three interrelated and complementary principles. First, we need a more robust understanding of the global governance architecture required, though a framework that integrates upfront the complexity of social-ecological systems, considers the structure-how the past constraints innovation at present - and agency - our capacity to innovate and shape the future-dualism in a flexible way, and warrants interoperability with other complexitybased approaches (Biermann and Kim 2020). Second, complexity modelling must consider the multidimensional relationship between social inequality and the intertwined dynamics of social-ecological systems, which occur across multiple spatial, temporal, and organizational levels (Hamman et al. 2018), and is affected by power asymmetries and actors with strong vested interests that are able to effortlessly influence (undesirable) systemic policy outcomes (Österblom et al. 2015, Gaffney et al. 2018). Last, but not least, as part of a wider process of democratization of public health policy, our mental leap must be accompanied by a vigorous involvement of stakeholders in the co-production of knowledge about zoonotic diseases (Bardosh et al. 2017). In my view, the activation of these three principles would increase the likelihood of reaching broad consensuses and the social legitimation that the coming difficult decisions to be made and tough trade-offs to be tackled will need, based on a shared understanding of the ecological, socio-political and power dynamics underlying pandemics.

\section{Conclusion}

Here, I have proposed an approach that can serve as an intermediary enabling the use of innovative complexity-based approaches in policy making aimed at assessing and managing Anthropocene risk. It is constituted by three core components operating at philosophical (modulating contingency), methodological (adaptive inference) and epistemic (blue uncertainty) levels. I argue that the power of my approach relies on its resonating properties with the mainstream mindset pervading current policy making in general, which emphasizes a focus on prediction and control regarding the resolution of high uncertainty situations and "wicked problems", and is pervaded by a reductionist epistemology that is ill-equipped to deal with complex global systemic risks. My approach can be useful for policy and decision makers 
facing situations like COVID-19 or, more generally, global environmental change, which characterized by radical uncertainty and ambiguity, for three main reasons. First, they make explicit two interrelated tensions: (1) the one created by the notion of contingency, hence the usefulness of richer frameworks including theories, propositions and perspectives from a more diverse range of modes of knowing for dealing with uncertainty; (2) the one created by the risk and uncertainty dyad as understood above, hence the critical importance of setting an epistemic limit between the two in order to prevent the turning of what we do not know-a radical uncertainty - into a manageable risk - for naïve reasons or, more grievously, due to political ambiguity or the influence of powerful actors. Second, frameworks similar to the adaptive inference protocol confer policy making and knowledge co-production an indispensable degree of flexibility and a learning function to deal with radical uncertainty, through a methodological capability to robustly progress from an initial blooming of competing theories, explanations and perspectives, to a narrower set of plausible ones in a participatory way. Finally, blue uncertainty pretends to inspire us to keep on working in solving the puzzles that threaten our social and ecological wellbeing, but raising awareness of our epistemic fallibility, or our cognitive limitations to reduce what, in the end, might truly be pure randomness in reality or our models of it.

\section{Acknowledgements}

In loving memory of Gabriel ("little fish"), taken by the sea, and F. J. Fernández Segura, my father, taken by COVID-19. A very special thought goes to the inspiring work of C. S. ("Buzz") Holling. All views expressed are mine and not necessarily of my organizations.

\section{References}

Andersen, I., and Rockström, J. 2020. COVID-19 Is a symptom of a bigger problem: Our planet's ailing health. Available at: https://time.com/5848681/covid-19-world-environmentday/ [Accessed June 8, 2020]

Angelstam, P., Andersson, K., Annerstedt, M., Axelsson, R., Elbakidze, M., Garrido, P., Grahn, P., Jönsson, K.I., Pedersen, S., Schlyter, P., Skärbäck, E., Smith, M., and Stjernquist, I. 2013. Solving Problems in Social-Ecological Systems: Definition, Practice and Barriers of Transdisciplinary Research. AMBIO 42: 254 - 265. https://doi.org/10.1007/s13280-012-0372$\underline{4}$

Arrow, K., Bolin, B., Costanza, R., Dasgupta, P., Folke, C., Holling, C.S., Gansson, B-O., Levin, S., Mäler, K-G., Perrings, C., and Pimentel, D. 1996. Economic growth, carrying capacity, and the environment. Environment and Development Economics 1: 104-110. https://www.jstor.org/stable/44378812

Arthur, W.B., Beinhocker, E.D., and Stanger, A. (editors). 2019. Complexity economics. Proceedings of the Santa Fe Institute's 2019 Fall Symposium. 
Avishai, B. 2020. The pandemic isn't a black swan but a portent of a more fragile global system. The New Yorker. Available at: https://www.newyorker.com/news/daily-comment/thepandemic-isnt-a-black-swan-but-a-portent-of-a-more-fragile-global-system [Accessed May 28, 2020]

Ball, J. 2020. Can we trust Neil Ferguson's computer code? The Spectator. Available at: https://www.spectator.co.uk/article/forget-ferguson-s-personal-failures-it-s-his-science-thatneeds-scrutiny [Accessed May 30, 2020]

Bardosh, K.L., Scoones, J.C., Grace, D., Kalema-Zikusoka, G., Jones, K.E., de Balogh, K., Waltner-Toews, D., Bett, B., Welburn, S.C., Mumford, E., and Dzingirai, V. 2017. Engaging research with policy and action: what are the challenges of responding to zoonotic disease in Africa? Philos. Trans. R. Soc. Lond., B, Biol. Sci. 372. https://doi.org/10.1098/rstb.2016.0172

Bar-Yam, Y. 2020. Transition to Extinction. New England Complex Systems Institute. Available at: https://necsi.edu/transition-to-extinction [Accessed May 19, 2020]

Baxter, R., Jemberie, W.B., Li, X., Naseer, M., Pauelsen, M., Shebehe, J., Viklund, E.W.E., Xia, X., Zulka, L.E., and Badache, A. 2020. COVID-19: Opportunities for interdisciplinary research to improve care for older people in Sweden. Scand J Public Health 140349482096954. https://doi.org/10.1177/1403494820969544

Biermann, F., and Kim, R. eds. 2020. Architectures of earth system governance: Institutional complexity and structural transformation. Cambridge: Cambridge University Press.

Bontempi, E., Vergalli, S., and Squazzoni, F. 2020. Understanding COVID-19 diffusion requires an interdisciplinary, multi-dimensional approach. Environmental research 188: 109814. https://doi.org/10.1016/j.envres.2020.109814

Brandt, P., Ernst, A., Gralla, F., Luederitz, C., Lang, D.J., Newig, J., Reinert, F., Abson, D.J., von Wehrden, and H. 2013. A review of transdisciplinary research in sustainability science. Ecological Economics 92: 1-15. https://doi.org/10.1016/j.ecolecon.2013.04.008

Castro, M., Ares, S., Cuesta, J.A., and Manrubia, S. 2020. The turning point and end of an expanding epidemic cannot be precisely forecast. PNAS 117: 26190-26196. https://doi.org/10.1073/pnas.2007868117

Cheng, V.C.C., Lau, S.K.P., Woo, P.C.Y., and Yuen, K.Y. 2007. Severe acute respiratory syndrome coronavirus as an agent of emerging and reemerging infection. Clinical Microbiology Reviews 20, 660-694. https://doi.org/10.1128/CMR.00023-07

Cirillo, P., and Taleb, N.N., 2020. Tail risk of contagious diseases. Nat. Phys. 16, 606-613. https://doi.org/10.1038/s41567-020-0921-X 
Desvars-Larrive, A., Dervic, E., Haug, N., Niederkrotenthaler, T., Chen, J., Di Natale, A., Lasser, J., Gliga, D.S., Roux, A., Sorger, J., Chakraborty, A., Ten, A., Dervic, A., Pacheco, A., Jurczak, A., Cserjan, D., Lederhilger, D., Bulska, D., Berishaj, D., Tames, E.F., Álvarez, F.S., Takriti, H., Korbel, J., Reddish, J., Grzymała-Moszczyńska, J., Stangl, J., Hadziavdic, L., Stoeger, L., Gooriah, L., Geyrhofer, L., Ferreira, M.R., Bartoszek, M., Vierlinger, R., Holder, S., Haberfellner, S., Ahne, V., Reisch, V., Servedio, V.D.P., Chen, X., Pocasangre-Orellana, X.M., Garncarek, Z., Garcia, D., and Thurner, S. 2020. A structured open dataset of government interventions in response to COVID-19. Scientific Data 7: 285. https://doi.org/10.1038/s41597-020-00609-9

Eagle, A. 2005. Randomness is unpredictability. British Journal for the Philosophy of Science 56(4): 749-790. https://doi.org/10.1093/bjps/axi138

Eker, S. 2020. Validity and usefulness of COVID-19 models. Humanities and Social Sciences Communications 7: 1-5. https://doi.org/10.1057/s41599-020-00553-4

Ferguson, N., Laydon, D., Nedjati Gilani, G., Imai, N., Ainslie, K., Baguelin, M., Bhatia, S., Boonyasiri, A., Cucunuba Perez, Z., Cuomo-Dannenburg, G., Dighe, A., Dorigatti, I., Fu, H., Gaythorpe, K., Green, W., Hamlet, A., Hinsley, W., Okell, L., Van Elsland, S., Thompson, H., Verity, R., Volz, E., Wang, H., Wang, Y., Walker, P., Winskill, P., Whittaker, C., Donnelly, C., Riley, S., and Ghani, A. 2020. Report 9: Impact of non-pharmaceutical interventions (NPIs) to reduce COVID19 mortality and healthcare demand. Imperial College London. https://doi.org/10.25561/77482

Foxon, T.J. 2013. Responding to the financial crisis: Need for a new economics. Environmental Innovation and Societal Transitions 6: 126-128. https://doi.org/10.1016/j.eist.2012.12.002

Frankel, J. 2020. Black Swans like COVID-19 are predictable. Views on the Economy and the World, March 30, 2020. Available at: https://www.belfercenter.org/publication/black-swanscovid-19-are-predictable

Frutos, R., Lopez-Roig, M., Serra-Cobo, J., and Devaux, C.A. 2020. COVID-19: The conjunction of events leading to the coronavirus pandemic and lessons to learn for future threats. Frontiers in Medicine 7. https://doi.org/10.3389/fmed.2020.00223

Funtowicz, S.O., and Ravetz, J.R. 1993. Science for the post-normal age. Futures 25(7): 739755.

Ge, X.-Y., Li, J.-L., Yang, X.-L., Chmura, A.A., Zhu, G., Epstein, J.H., Mazet, J.K., Hu, B., Zhang, W., Peng, C., Zhang, Y.-J., Luo, C.-M., Tan, B., Wang, N., Zhu, Y., Crameri, G., Zhang, S.-Y., Wang, L.-F., Daszak, P., and Shi, Z.-L. 2013. Isolation and characterization of a bat SARS-like coronavirus that uses the ACE2 receptor. Nature 503, 535-538. https://doi.org/10.1038/nature12711 
Gaffney, O., Crona, B., Dauriach, A., and Galaz, V. 2018. Sleeping financial giantsOpportunities in financial leadership for climate stability. Published by Global Economic Dynamics and the Biosphere programme, Future Earth and the Stockholm Resilience Centre. https://doi.org/10.17045/sthlmuni.7105748

GNDE. 2020. Green New Deal for Europe. Available at: https://www.gndforeurope.com [Accessed June 1, 2020]

Gordon, L.J. 2020. The Covid-19 pandemic stress the need to build resilient production ecosystems. Agriculture and Human Values. Available at: https://doi.org/10.1007/s10460-02010105-w [Accessed May 27, 2020]

Guo, Y.-R., Cao, Q.-D., Hong, Z.-S., Tan, Y.-Y., Chen, S.-D., Jin, H.-J., Tan, K.-S., Wang, D.Y., and Yan, Y. 2020. The origin, transmission and clinical therapies on coronavirus disease 2019 (COVID-19) outbreak-An update on the status. Military Medical Research 7(1): 11. https://doi.org/10.1186/s40779-020-00240-0

Hall, N. 2017. What is adaptation to climate change? Epistemic ambiguity in the climate finance system. International Environmental Agreements: Politics, Law and Economics 17(1): 37-53. https://doi.org/10.1007/s10784-016-9345-6

Halpern, S.D., Truog, R.D., and Miller, F.G. 2020. Cognitive bias and public health policy during the COVID-19 pandemic. JAMA 324: 337. https://doi.org/10.1001/jama.2020.11623

Hamann, M., Berry, K., Chaigneau, T., Curry, T., Heilmayr, R., Henriksson, P.J.G., HentatiSundberg, J., Jina, A., Lindkvist, E., Lopez-Maldonado, Y., Nieminen, E., Piaggio, M., Qiu, J., Rocha, J.C., Schill, C., Shepon, A., Tilman, A.R., van den Bijgaart, I., and Wu, T. 2018. Inequality and the Biosphere. Annual Review of Environment and Resources 43: 61-83. https://doi.org/10.1146/annurev-environ-102017-025949

He, X., Lau, E.H.Y., Wu, P., Deng, X., Wang, J., Hao, X., Lau, Y.C., Wong, J.Y., Guan, Y., Tan, X., Mo, X., Chen, Y., Liao, B., Chen, W., Hu, F., Zhang, Q., Zhong, M., Wu, Y., Zhao, L., Zhang, F., Cowling, B.J., Li, F., Leung, G.M., 2020. Temporal dynamics in viral shedding and transmissibility of COVID-19. Nat Med 26: 672 - 675. https://doi.org/10.1038/s41591$\underline{020-0869-5}$

Holling, C.S., and Allen, C.R. 2002. Adaptive inference for distinguishing credible from incredible patterns in nature. Ecosystems 5: 319-328. https://doi.org/10.1007/s10021-001$\underline{0076-2}$

Huang, N.E., Qiao, F., Wang, Q., and Tung, K-K. 2020. Herd immunity vs suppressed equilibrium in COVID-19 pandemic: different goals require different models for tracking. medRxiv: p.2020.03.28.20046177 
IIF. 2020. COVID-19: Ioannidis vs. Taleb. International Institute of Forecasters. Available at: https://forecasters.org/blog/2020/06/14/covid-19-ioannidis-vs-taleb/ [Accessed June 06, 2020]

ILO (International Labour Organization). 2020. Country policy responses (COVID-19 and the world of work). Available at: https://www.ilo.org/global/topics/coronavirus/countryresponses/lang--en/index.htm\#GB [Accessed May 31, 2020]

IPBES. 2020. Workshop report on biodiversity and pandemics of the Intergovernmental Platform on Biodiversity and Ecosystem Services. Daszak, P., das Neves, C., Amuasi, J., Hayman, D., Kuiken, T., Roche, B., Zambrana-Torrelio, C., Buss, P., Dundarova, H., Feferholtz, Y., Foldvari, G., Igbinosa, E., Junglen, S., Liu, Q., Suzan, G., Uhart, M., Wannous, C., Woolaston, K., Mosig Reidl, P., O'Brien, K., Pascual, U., Stoett, P., Li, H., Ngo, H. T., IPBES secretariat, Bonn, Germany. https://doi.org/10.5281/zenodo.4147317

Ioannidis, J.P.A., Cripps, S., and Tanner, M.A. 2020 Forecasting for COVID-19 has failed. 2020. International Institute of Forecasters. Available at: https://forecasters.org/blog/2020/06/14/forecasting-for-covid-19-has-failed// [Accessed June 06, 2020]

Keys, P.W., Galaz, V., Dyer, M., Matthews, N., Folke, C., Nyström, M., and Cornell, S.E. 2019. Anthropocene risk. Nat Sustain 2: 667-673. https://doi.org/10.1038/s41893-019-0327$\underline{x}$

Kay, J., and King, M. 2020. Radical Uncertainty: Decision-making for an unknowable future. London: The Bridge Street Press.

Keynes, J. M. 1921. A treatise on probability. Cornell University Library.

Kissler, S.M., Tedijanto, C., Goldstein, E., Grad, Y.H., and Lipsitch, M. 2020. Projecting the transmission dynamics of SARS-CoV-2 through the postpandemic period. Science 368(6493): 860 - 868. https://doi.org/10.1126/science.abb5793

Knight, F. H. 1921. Risk, uncertainty, and profit. The University of Chicago press.

Kumar, M., Taki, K., Gahlot, R., Sharma, A., and Dhangar, K. 2020. A chronicle of SARSCoV-2: Part-I - Epidemiology, diagnosis, prognosis, transmission and treatment. Science of The Total Environment 734: 139278. https://doi.org/10.1016/j.scitotenv.2020.139278

Lee, J. 2012. Mental Leap. In: Seel, N.M. (Ed.), Encyclopedia of the Sciences of Learning. Springer US, Boston, MA, pp. 2194-2194. https://doi.org/10.1007/978-1-4419-1428-6 1557 Mahoney, J. 2000. Path dependence in historical sociology. Theory and Society 29(4): 507548. https://www.jstor.org/stable/3108585 
Maechler, S., and Graz, J.-C. 2020. Is the sky or the earth the limit? Risk, uncertainty and nature. Review of International Political Economy 0: $1-22$. https://doi.org/10.1080/09692290.2020.1831573

Mallee, H. 2020. A time for transdisciplinarity'. Current Opinion in Environmental Sustainability, November, S1877343520300853. https://doi.org/10.1016/j.cosust.2020.09.011

McGillivray, G. 2020. Coronavirus is significant, but is it a true black swan event? The Conversation. Available at: http://theconversation.com/coronavirus-is-significant-but-is-it-atrue-black-swan-event-136675 [Accessed May 28, 2020]

Menachery, V.D., Yount, B.L., Sims, A.C., Debbink, K., Agnihothram, S.S., Gralinski, L.E., Graham, R.L., Scobey, T., Plante, J.A., Royal, S.R., Swanstrom, J., Sheahan, T.P., Pickles, R.J., Corti, D., Randell, S.H., Lanzavecchia, A., Marasco, W.A., and Baric, R.S. 2016. SARSlike WIV1-CoV poised for human emergence. Proc. Natl. Acad. Sci. U.S.A. 113, 3048-3053. https://doi.org/10.1073/pnas.1517719113

Méndez, P.F., Amezaga, J.M., and Santamaría, L. 2019. Explaining path dependent rigidity traps: increasing returns, power, discourses and entrepreneurship intertwined in socialecological systems. Ecology and Society 24(2): 30. https://doi.org/10.5751/ES-10898-240230

Molas-Gallart, J., Boni, A., Schot, J., and Giachi, S. 2020. A formative approach to the evaluation of Transformative Innovation Policy. TIPC Working Paper, TIPCWP2020-01. Available at: http://www.tipconsortium.net/wp-content/uploads/2020/07/Paper-FORETIP1.pdf

Moore, C. 2020. Transmission T-024: Cristopher Moore on the heavy tail of outbreaks. Santa Fe Institute. Available at: https://www.santafe.edu/news-center/news/transmission-t-024cristopher-moore-on-the-heavy-tail-of-outbreaks [Accessed May 22, 2020]

Morse, S.S. ed. 1996. Emerging viruses. New York, NY: Oxford University Press.

Naidoo, R., and Fisher, B. 2020. Reset Sustainable Development Goals for a pandemic world. Nature 583: 198-201. https://doi.org/10.1038/d41586-020-01999-x

Norman, J., Bar-Yam, Y., and Taleb, N.N. 2020. Systemic Risk of Pandemic via Novel Pathogens-Coronavirus: A Note. New England Complex Systems Institute. Available at: https://necsi.edu/systemic-risk-of-pandemic-via-novel-pathogens-coronavirus-a-note

[Accessed May 25, 2020]

Norström, A.V., Cvitanovic, C., Löf, M.F., West, S., Wyborn, C., Balvanera, P., Bednarek, A.T., Bennett, E.M., Biggs, R., de Bremond, A., Campbell, B.M., Canadell, J.G., Carpenter, S.R., Folke, C., Fulton, E.A., Gaffney, O., Gelcich, S., Jouffray, J.-B., Leach, M., Le Tissier, M., Martín-López, B., Louder, E., Loutre, M.-F., Meadow, A.M., Nagendra, H., Payne, D., 
Peterson, G.D., Reyers, B., Scholes, R., Speranza, C.I., Spierenburg, M., Stafford-Smith, M., Tengö, M., van der Hel, S., van Putten, I., and Österblom, H. 2020. Principles for knowledge co-production in sustainability research. Nature Sustainability 3: 182-190. https://doi.org/10.1038/s41893-019-0448-2

North, D.C. 2005. Understanding the process of economic change. Princeton, N.J.: Princeton University Press.

OECD. 2019. Governance as an SDG accelerator: Country experiences and tools. OECD Publishing, Paris. https://doi.org/10.1787/0666b085-en

OECD. 2020. Addressing societal challenges using transdisciplinary research. OECD Science, Technology and Industry Policy Papers No. 88. OECD Publishing, Paris. https://doi.org/10.1787/0ca0ca45-en

Österblom, H., Jouffray, J.-B., Folke, C., Crona, B., Troell, M., Merrie, A., and Rockström, J. 2015. Transnational Corporations as 'Keystone Actors'. Marine Ecosystems. PLoS ONE 10: e0127533. https://doi.org/10.1371/journal.pone.0127533

Ostrom, E. 2007. A diagnostic approach for going beyond panaceas. Proceedings of the National Academy of Sciences 104(39): 15181-15187. https://doi.org/10.1073/pnas.0702288104

Panovska-Griffiths, J. 2020. Coronavirus: we've had 'Imperial', 'Oxford' and many more models-but none can have all the answers. The Conversation. Available at: http://theconversation.com/coronavirus-weve-had-imperial-oxford-and-many-more-modelsbut-none-can-have-all-the-answers-135137 [Accessed May 30, 2020]

Phillips, C.A., Caldas, A., Cleetus, R., Dahl, K.A., Declet-Barreto, J., Licker, R., Merner, L.D., Ortiz-Partida, J.P., Phelan, A.L., Spanger-Siegfried, E., Talati, S., Trisos, C.H., and Carlson, C.J. 2020. Compound climate risks in the COVID-19 pandemic. Nature Climate Change 10: 586-588. https://doi.org/10.1038/s41558-020-0804-2

Ritchie, H. Roser, M., Ortiz-Ospina, E., and Hasell, J. 2020. Policy Responses to the Coronavirus Pandemic - Statistics and Research. Our World in Data. Available at: https://ourworldindata.org/policy-responses-covid [Accessed May 31, 2020]

Rittel, H.W.J., and Webber, M.M. 1973. Dilemmas in a general theory of planning. Policy Sciences 4(2): 155-169. https://doi.org/10.1007/BF01405730

Sachs, J.D., Schmidt-Traub, G., Mazzucato, M., Messner, D., Nakicenovic, N., and Rockström, J. 2019. Six Transformations to achieve the Sustainable Development Goals. Nature Sustainability 2: 805-814. https://doi.org/10.1038/s41893-019-0352-9 
Scagliarini, A., and Alberti, A. 2020. COVID-19: An appeal for an intersectoral approach to tackle with the emergency. Front. Public Health 8. https://doi.org/10.3389/fpubh.2020.00302

Settele, J., Díaz, S., Brondizio, E., and Daszak, P. 2020. IPBES Guest article: COVID-19 stimulus measures must save lives, protect livelihoods, and safeguard nature to reduce the risk of future pandemics. Available at: https://ipbes.net/covid19stimulus [Accessed May 19, 2020]

Shen, C., Taleb, N.N., and Bar-Yam, Y. 2020. Review of Ferguson et al "Impact of nonpharmaceutical interventions...”. New England Complex Systems Institute. Available at: https://necsi.edu/review-of-ferguson-et-al-impact-of-non-pharmaceutical-interventions

[Accessed May 31, 2020]

Sieron, A. 2020. Does the COVID-19 pandemic refute probability neglect? Journal of Risk Research 0: 1-7. https://doi.org/10.1080/13669877.2020.1772346

Taleb, N.N. 2007. The black swan: The impact of the highly improbable 1st ed. New York: Random House.

Taleb, N.N. On single point forecasts for fat tailed variables. 2020. International Institute of Forecasters. Available at: https://forecasters.org/blog/2020/06/14/on-single-point-forecastsfor-fat-tailed-variables/ [Accessed June 06, 2020]

Taylor, L.H., Latham, S.M., and Woolhouse, M.E. 2001. Risk factors for human disease emergence. Philos. Trans. R. Soc. Lond., B, Biol. Sci. 356: 983-989. https://doi.org/10.1098/rstb.2001.0888

The New York Times. 2020. Destroying nature unleashes infectious diseases. Available at: https:/www.nytimes.com/2012/07/15/sunday-review/the-ecology-of-disease.html [Accessed May 19, 2020].

Thornton, T.B. 2018. From Economics to Political Economy: The problems, promises and solutions of pluralist economics. New York: Routledge.

UNEP (United Nations Environment Program). 2020. Record global carbon dioxide concentrations despite COVID-19 crisis. UN Environment. Available at: http://www.unenvironment.org/news-and-stories/story/record-global-carbon-dioxideconcentrations-despite-covid-19-crisis [Accessed June 1, 2020]

van Dorp, L., Acman, M., Richard, D., Shaw, L.P., Ford, C.E., Ormond, L., Owen, C.J., Pang, J., Tan, C.C.S., Boshier, F.A.T., Ortiz, A.T., Balloux, F. 2020. Emergence of genomic diversity and recurrent mutations in SARS-CoV-2. Infection, Genetics and Evolution 83: 104351. https://doi.org/10.1016/j.meegid.2020.104351 
Vincent, K., Carter, S., Steynor, A., Visman, E., Wågsæther, and K.L. 2020. Addressing power imbalances in co-production. Nature Climate Change 10: 877-878. https://doi.org/10.1038/s41558-020-00910-w

Waltner-Toews, D. 2017. Zoonoses, One Health and complexity: wicked problems and constructive conflict. Philosophical Transactions of the Royal Society B: Biological Sciences 372(1725): p.20160171. https://dx.doi.org/10.1098\%2Frstb.2016.0171

Webster, R.G. 2004. Wet markets - a continuing source of severe acute respiratory syndrome and influenza? The Lancet 363(9404): 234-236. https://doi.org/10.1016/S0140$\underline{6736(03) 15329-9}$

Wilke, C.O., and Bergstrom, C.T. 2020. Predicting an epidemic trajectory is difficult. PNAS 117: 28549-28551. https://doi.org/10.1073/pnas.2020200117

Woloshin, S., Patel, N., and Kesselheim, A.S. 2020. False Negative Tests for SARS-CoV-2 Infection-Challenges and Implications. New England Journal of Medicine 383: e38. https://doi.org/10.1056/NEJMp2015897

World Economic Forum. 2020. Biodiversity loss is hurting our ability to combat pandemics. Available at: https:/www.weforum.org/agenda/2020/03/biodiversity-loss-is-hurting-ourability-to-prepare-for-pandemics/ [Accessed May 19, 2020]

WHO (World Health Organization). 2020. Pandemic fatigue-Reinvigorating the public to prevent COVID-19. Policy framework for supporting pandemic prevention and management. Copenhagen: WHO Regional Office for Europe. 